Original scientific article

UDC: $616.927-036.22(497.11) " 1914 / 1915 "$

DOI: $10.25106 / \mathrm{ahm} .2018 .1212$

\author{
Milovan Pisarri \\ Centre for Public History \\ 11000 Belgrade, Serbia \\ E-mail: milovan.pisarri@gmail.com
}

\title{
THE TYPHUS EPIDEMIC IN SERBIA IN 1915: THE ROLE OF DR RICHARD STRONG'S AMERICAN MEDICAL MISSION
}

\begin{abstract}
The checked typhus epidemic broke out in Serbia in late 1914 and soon spread to most parts of the country. Faced with a shortage of doctors and medical equipment, the Serbian government turned to allied and neutral countries for help. Doctors, even entire medical missions, from various European countries, especially from the United Kingdom and France, started coming. The enormous number of victims, among soldiers and Austro-Hungarian prisoners, as well as among the civilian population, revealed the dimension of the epidemic. The fear that the typhus would affect other European countries, even the United States, started to settle in. In March 1915 , in order to prevent the spread of the disease across the borders of the Kingdom of Serbia, among other things, the American Red Cross and the Rockefeller Foundation, with the help of Serbs who lived in America, set up a special medical commission led by Dr Richard Strong, a well-known epidemiologist. The mission arrived to Serbia in early April and successfully coordinated the fight against typhus in cooperation with already present missions. In that sense, Strong was one of the most credited doctors in eradicating the disease. According to the estimates at the time, typhus took around 150,000 lives.
\end{abstract}

Key words: typhus, World War I, Serbia

Non MeSH: American Mission, Richard Strong 


\section{Introduction}

In recent years, in Serbia as well as in other European countries, marking various events from World War I received a lot of attention. New publications, exhibitions, seminars and round tables presented the results of new research and interpretations, or simply reworked the already familiar, mostly military, political and diplomatic topics. ${ }^{1}$ On the other hand, attention rarely focused on to topics related, for example, to social history, history of medicine, or economic history. Speaking of events in Serbia between 1914 and 1918, one of the topics that remained in the shade and did not find a suitable place in the public commemorations or scientific meetings (and publications) is the typhus epidemic and great efforts to suppress it. Although research works on this subject already exist, ${ }^{2}$ many of its aspects have remained hidden. For this reason, the focus of this article will be on the typhus epidemic, but also on the US medical mission which arrived in Serbia in the spring of 1915 and played an important role in the complete eradication of the disease.

\section{The Typhus Epidemic}

The events of the second half of 1914 disrupted life in Serbia. The numerous battles had exhausted the army, which, despite all odds, had managed to thwart the actions of the Austro-Hungarian troops. Many civilians had escaped from the border areas or from those in which they had been victims of atrocious crimes, pouring into the small towns of south-central Serbia which suddenly swelled into large centers, populated by tens of thousands of people. About 60,000 Austro-Hungarian prisoners, many of whom were wounded and sick, were added to the refugees and the army which, too, had many casualties. Accommodation and livelihood had to be found for them too and the already crowded Serbian towns, without sewage and water supply systems, paved streets or buildings capable of accommodating those already living in the towns, were unable to resist for much longer.

In this situation of general turmoil, with the lack of food, medicines and clothing, very poor sanitation and extreme mixing of people, a spotted typhus epidemic that would cause the death of tens of thousands of people broke out.

Based on the observations of numerous scientists at the time, the disease first appeared among the Austro-Hungarian prisoners. According to some sources, of the 60,000 soldiers left in the lurch by their superiors, about 3,500 showed all the symptoms. [1] Those who first examined them agreed that the typhus had come to Serbia together with the troops from Galicia who had been relocated to the Balkan front, bringing with them the louse responsible for transmitting the disease and that the epicenter in Serbia was in the town of Valjevo, where most of them were concentrated. [1 p95,115, 2]

1 For the most important public events, see: http://www.greatwar.co.uk/events/2014-2018-ww1-centenary-events.htm.

2 The text used the most important works on typhus in Serbia in 1915 in Serbian and English. 
When the Serbian army entered the town, no measures necessary to isolate the disease were undertaken. The area was not quarantined; instead, the Austro-Hungarian prisoners were distributed to various regions of the country without having separated the sick from the injured or those in good health: they went from Skopje to Knjaževac, Kraljevo, Niš, where they arrived after long marches. [3] The soldiers found themselves huddled in large open or enclosed spaces, in close contact with each other, in conditions of high turnover of people. Weakened, without appropriate support, although the Serbian authorities gave them everything they could, [3 p42] and in precarious hygiene conditions, without health services, without beds and psychologically devastated, these prisoners constituted an ideal ground for the spread of the epidemic.

The typhus was also quickly transmitted to the Serbian troops and to the numerous refugees that crowded the main towns. Despite this, the authorities initially failed to understand of the seriousness of the phenomenon, which caused a further spread of the disease, so it literally reached every corner of the country by January 1915. The refugees, including those who already had the first symptoms of the disease, were not prevented from returning to their homes $[4,5]$ once again because their presence was a serious hindrance to the army's movements. From the towns, the typhus reached the countryside, generating a situation that was getting out of control.

Meanwhile, no measures were taken within the army either. In fact, anyone who presented with any fever was simply entrusted to the care of military hospitals, the capacities of which had been otherwise much reduced, often finding themselves sharing rooms, bathrooms and even beds with health facilities already crawling with typhus patients.

Other factors were also conducive to the rapid spread of the disease: the very buildings that operated as military hospitals were often converted for this purpose but without the minimum requirements for patient care (absence of separate rooms, bathrooms, kitchens, or, simply, sinks). ${ }^{3}$ Entry into these facilities was not accompanied by sterilization or disinsfestation; the clothes were not changed or washed; [4 p5] the sick did not receive the necessary rations of food and liquids, especially of water and milk; they did not receive medical treatment, and, being unable to get out of bed (or from the floor, since beds were not available for everyone), they were compelled to lie in their excrement.

It was at that point that the extreme fragility of the Serbian health care system became evident. When the war against the Ottoman Empire broke out in the autumn of 1912, that is, when a series of armed conflicts began which, in the case of Serbia, would last until 1918, the Ministry of Defense calculated that there were 370 doctors in Serbia, 296 of whom had been mobilized. [6]

3 In Valjevo there were already 12 permanent hospitals and 12 temporary ones, which made use of all available spaces, including restaurants, schools and other venues capable of admitting an increased number of patients. [1 p23] 
Two years later, by the time of the expiry of the Austro-Hungarian ultimatum, the situation had not improved at all. At the beginning of the Great War, there were about 350 doctors in Serbia, and, like in the previous two years, most of them were recruited in the army and placed at the service of the war needs.

When the typhus epidemic broke out, these doctors were the first to be affected by the severity of the disease: of those 350 , as many as 126 fell victim to the typhus already in the first bout of the epidemic. Entire military hospitals remained without doctors, [4 p3-4] clearly running the risk of total extinction of doctors across the country. The death of medical personnel revealed the primitive knowledge of the required remedies and the absence of any medicines and health supplies: typhus was fought with traditional remedies, using natural medicines, brandy compresses, wine vinegar and garlic and with the use of sulfur and mothballs in clothes. The only medicines in use were aspirin, quinine and salicylic acid [1 p24] while health checks along the main communication routes (i.e. on the Thessaloniki-Belgrade railway) were very poor and the disinsfestation methods used remained completely primitive and inefficient for a long time. [7]

\section{The struggle for survival}

The initial response to the shortage of staff and lack of knowledge was organised by recruitment of health professionals among the prisoners. In Niš, the Serbian army incorporated 50 Austrian medical officers into its ranks; however, their struggle, like that of the Serbian doctors, was almost in vain due to the lack of medicines and means of disinfection, of facilities and beds, of clothes and linen for the sick. ${ }^{4}$ Shortly thereafter, the foreign surgeons already present in the country, such as Dutchman Arius Van Tienhoven, were relieved of their duties and put in charge of the treatment of typhus, but the results were again poor. It quickly became clear, both among the members of the government, and the army leaders, that Serbia could not defeat the epidemic on its own and that the outcome could be disastrous. Appeals were launched to the allied and neutral countries, as had been done before to obtain aid for wounded soldiers. It was obvious to everyone that the epidemic affected not only soldiers but also numerous civilians whose condition required immediate intervention. Still, neither the allied governments nor the numerous organizations that had already been active in organizing aid to the civilian population of Belgium and northern France under German occupation proved ready to take up the appeals from Belgrade: the constant hope that the allies would recognize the importance of the southern front and the victories of the Serbian army would once again dwindle into thin air.

In order to try to deal with the epidemic as soon as possible, while waiting for the allied governments to take some action to alleviate at least the suffering of the Serbian troops, a real recruitment of doctors, nurses and foreign specialists was then

4 In January 1915 Fraccaroli notes that 29 Austrian doctors already died of typhus. [3 p42] 
carried out on particularly advantageous terms for those who accepted. On $26^{\text {th }}$ January 1915, the Ministry of Defense referred to the Ministry of Foreign Affairs with a request to find, through the various diplomatic representatives in the allied and neutral countries, at least fifty doctors willing to travel to Serbia. [8]

A particular hope was placed once again in Russia, always considered in Serbia as the power to look up to. While the ambassadors in Rome and Athens, who were asked to urgently hire between fifteen and twenty doctors at pre-established economic conditions - salaries of 500-600 dinars, food, lodging and travel expenses - the Serbian representative in Petrograd was simply asked if Russia could "send experienced doctors and under what conditions". [9]

With this exception, paid employment of health professionals through diplomatic offices in Europe continued. [10] The appeal was quickly extended also to researchers and scientists, to anyone who was able to contribute to the fight against typhus. On $1^{\text {st }}$ March, in a letter to the Ministry of Foreign Affairs, the Ministry of the Interior requested to make inquiries via the diplomatic representative in Paris if any doctor from the Pasteur Institute in Paris would be willing to go to Serbia "with the equipment necessary to do research and eventually experiment with new therapies in the treatment of exanthematic typhus". [11] These words clearly illustrated how desperate the situation was: despite the apparently calm and diplomatic tones, the possibility of carrying out experiments on the many sick Serbs in an attempt to improve their condition was openly offered. ${ }^{5}$

In mid-March, requests for medical personnel became more pressing and were accompanied by additional economic benefits for those who accepted; there were also thefirst signs that medical care would also be extended to civilians. Until then the army had had absolute precedence.

The representative in Paris was told that it would be possible to hire three hundred doctors and more, under very precise conditions: in addition to salaries and travel expenses, for those who were willing to visit civilians in the villages, per diems and additional payments were guaranteed for each medical examination and for each successful vaccination, as well as the possibility of concluding agreements with the local authorities to obtain some sort of annual payments. [13]

A new appeal for the recruitment of 50 doctors was launched on $30^{\text {th }}$ March to the legations in France and Switzerland, in which the financial clauses were reaffirmed and further compensation was added: if they were to fall victim to the disease in Serbia, the families of doctors were to be paid the sum of 10,000 dinars in silver. 14]

This recruitment of foreign medical personnel, with the Serbian government acting, in a certain sense, as the operational hub from which various proposals and job offers were launched through its consular branches, was not, however, sufficient.

5 The experiments were actually successively carried out in Serbia during the typhus epidemic in the Austria-Hungary, Galicia and Bulgaria. [12] 
The operation then gained important momentum in some organizations established abroad thanks to the work of Serbian emigrants or people who felt in some way connected to the fate of the small Balkan country. Some of these organizations had already been active from the previous summer-autumn and simply expanded their range of action; many others emerged during the typhus epidemic with the explicit task of assisting both the military and the civilian population.

With the help of these organizations, real health missions were funded and sent to Serbia, usually made up of volunteers, the organization of which still required large sums of money (travel, procurement of materials and equipment, supplies, etc.). Predominantly women departed this time, their motivations diametrically opposed to those of their colleagues who had replied, it seems, more often for professional than for humanitarian reasons; ${ }^{6}$ entire missions were composed of and run by women, important hospitals were entrusted to their management and civilians were often able to receive treatment only thanks to their intervention.

Some of these organizations that operated in order to assist Serbian soldiers and civilians played a far more important role than what had remained of the Serbian health system. One such example was the "Serbian Relief Fund", founded in London on $23^{\text {rd }}$ September 1914 at the initiative of Robert William Seton-Watson, Arthur Evans, a professor at Oxford, and Bertram Christian, a journalist, the main objective of which was fundraising (thanks to the organization of cultural events and donations) and their subsequent posting to Serbia; during the typhus epidemic, the "Serbian Relief Fund" expanded its range of action and was able to send several missionsto Serbia that were able to organize themselves as permanent and autonomous hospitals, primarily intended for the care of the soldiers but which later had a fundamental role also among civilians.

Other relief committees emerged in Paris, Washington and other large cities; the English Red Cross was set in motion, and, in late January, it organized a 30-member health mission under the command of Captain Bennett. It soon seemed that the governments of the allied countries began to act directly, too: at the end of February, the British government sent a mission of 25 doctors - in its appeal addressed to London on $9^{\text {th }}$ February, Serbia had requested at least 100 [16] - between the end of February and the beginning of March, the French government organized the sending of a health mission made up of 100 doctors in four groups, entirely financed from Paris.

Thus, around 360 foreign doctors and nurses were shortly to find themselves working in Serbia, organized in 15 permanent missions, whose work was almost entirely dedicated to the care of Serbian soldiers. [17] There were very few exceptions, or missions organized explicitly to rescue civilians. Such an example was that of Princess Trubecki, who left from Petrograd on $2^{\text {nd }}$ February and whose mission was to

6 In this regard, some problems emerged with the Serbian authorities concerning payments, so much so that, in May 1915, the Ministry of the Interior invited the consulates to clearly establish the salaries and payment methods in advance, to avoid the embarrassing situations that had "already occurred". [15] 
open a canteen for refugees and victims, a "tea room" for the poor and, ultimately, a shelter for those suffering from epidemics. [18 ${ }^{7}$

Despite this, instead of being subdued, the epidemic seemed to be expanding even faster. In March, the government intervened to put in place more vigorous measures, introducing the ban for the refugees to return to their homes and preventing the movement of soldiers and civilians outside the areas where they were, save for exceptional reasons; the suspension of railway traffic was ordered until completion of the general disinfestation (which ended on $31^{\text {st }}$ March, but the suspension was extended until $15^{\text {th }}$ April). [1 p34-5, 16 p59] Once again, the measures proved to be completely inadequate. The disease continued to spread and reached its peak between the end of March and early April, when there were 9,000 new infections on average among the soldiers and civilians. [4 p125]

In the meantime, the high mortality rate generated a new and potentially very dangerous problem: the burial of the dead. Even there the typhus found fertile ground for further propagation: once again due to the lack of personnel, the corpses were not burned or buried immediately and heaps of lifeless men became new "stations" in which the epidemic (lice) found their natural environment for reproduction. Suddenly, it seemed that the situation was the same everywhere.

\section{The care provided to civilians}

At the end of winter, when two months had already passed since the outbreak of the epidemic and the victims were already counted in tens of thousands, the situation began to seriously alarm the European and American public. The newspapers of the allied and neutral countries reported the accounts of those who had seen the seriousness of the situation: "If you do not do something to prevent the spread of the disease, the country will lose more than half of its population," said Dr. Ryan, head of the American Red Cross unit in Serbia. [19]

Such a pestilence had not been seen for a very long time and the fear that the typhus could spread also to the rest of Europe began to hover even in those countries that felt distant from danger. In fact, it had not yet crossed the borders of Serbia, but if this were to happen, it would be difficult to avoid a general catastrophe that would affect the whole of Europe. [20]

The state of apprehension, however, did not concern only the Old Continent, because, it had already been a while that the United States had very strict measures to prevent anyone who had come into contact with the typhus to carry its germs across the ocean. [21]

This fear was one of the reasons that probably pushed the allied and neutral countries, andthe United States in particular, to invest a lot of energy in avoiding an "European" epidemic, the effects of which could not only kill hundreds of thousands

7 The mission included 25 persons and 7 wagons of supplies and was led personally by the princess; it was established in the building of the grammar school in Niš. 
of people or seriously compromise the course of the war, but could inflict a very serious blow on the very relations between Europe and America. ${ }^{8}$ To describe the danger of the disease, Dr. Breck Trowbridge, president of the Serbian Agricultural Policy Commission in New York claimed that if the United States had not taken these important measures, the scourge of typhus would have moved north to Austria, other European countries and, finally, to the United States. [23]

The fear of a pandemic was also emphasized by those who, far from the strategies and movements of the armies at war, assumed that the Austro-Hungarians had not yet ventured into new offensive against Serbia because of the fear of a mass contagion. [4 p3]

Reports alleging that typhus in Serbia was taking "violent proportions" and that immediate measures had to be taken to "protect Europe from an imminent and widespread epidemic", [23] were also taken into consideration by the "Rockefeller War Relief Commission", which had already decided to organize the sending of a special commission in late January to assess the situation among the non-combatant population in Serbia. Its task also included the organization of aid to be sent to the areas affected by the Austro-Hungarian crimes of the previous August; [24] yet, what left the biggest impression on its members during the journey (which took place between $19^{\text {th }}$ and $26^{\text {th }}$ February to the principal towns in Serbia) was the generally appalling hygienic and health situation. What was seen by its members was soon to become public knowledge, confirming the previous claims by various other observers: there had been several epidemic outbreaks in Serbia, but, among these, typhus was literally wiping out the lives of so many people, including several Serbian and foreign doctors; some units of the American Red Cross as well as the British ones had been forced to interrupt their activity because of that. The committee members themselves were the first to promote the idea of a major international health operation to deal with the epidemic. $[25,26]$

The requests that the Serbian government had already launched to the United States for more assistance at the end of 1914 (when the epidemic had not yet broken out), the appeals of the "Serbian Agricultural Relief Commission", supported by the reports of the members of the American Red Cross already working in Serbia and reinforced by the testimony of the Rockefeller Commission finally received a tangible response.

As early as the beginning of March, the American Red Cross, in collaboration with the Rockefeller Foundation, entrusted General Gorgas with the organization of a health mission to help in the fight against typhus and other epidemics in Serbia. Dr. Richard Strong, Director of the Harvard University Department of Tropical Medicine, was chosen as the doctor in charge of this mission. He had already distinguished

8 It should be noted, among other things, that the idea of a preventive intervention to avoid a Europe-wide pandemic had a very important role also in the subsequent typhus epidemics that scourged the Eastern front. [22] 
himself in the fight against the plague in China in 1911. Expert bacteriologists and health professionals were sent alongside him and all the necessary means and supplies were put at their disposal. This decision immediately aroused the hopes of many, so much so that, on $12^{\text {th }}$ March, Mabel Grujić ${ }^{9}$ advised the Serbian government to grant the Rockfeller mission, as it was then called, the full freedom of action, as it was composed of internationally renowned scientists and had almost unlimited funds; ${ }^{10}$ meanwhile, the Serbian Consul in New York assured that the Rockefeller Foundation "would do a lot for Serbia"; [28] and at the moment of his departure, General Gorgas proclaimed it, with a sense of pride, "the most efficient commission ever organized in the history of modern health care". [29]

In short, a special ship sailed from Boston with its cargo that included seventeen health equipment lots, [30] while the mission personnel would then arrive in Serbia in groups: some via Thessaloniki, others through Austria, Romania and Bulgaria. [31]

Meanwhile, on $30^{\text {th }}$ March, a preparatory conference was held in Paris for the organization of the fight against typhus, presided over by Georges Tusson, Head of the French government's Health Service. The participants of which included the American Red Cross Director Ernest Bicknell (who had already been part of the Rockefeller commission that had visited Serbia in February), some members of the English Red Cross and the French Ministry of War, and, finally, businessman Thomas Lipton. It was decided, inter alia, to coordinate the efforts of the already active missions and to divide Serbia into three areas under French, English and American responsibility. [32]

In order to act as efficiently as possible, Strong set off on $3^{\text {rd }}$ April and went first to Britain and France to consult with those who had already been part of similar commissions and had already personally seen the situation in Serbia. The arrival of the mission was eagerly awaited there and preparations were underway to ensure maximum availability to its members. Their movements were followed with great care [33] and Pašić himself recommended that they be sent directly to the provisional capital of Niš and that special care be taken of them. [34]

The arrival of Strong in Serbia was immediately followed by the setting up of an international operating committee for the eradication of infectious diseases, with Prince Alexander symbolically appointed as President; Sir Ralph Paget, supervisor of the English missions already operating in the territory became its Vice President. Following the directives of the Paris meeting, members of the great powers' missions that were already engaged in Serbia were also included: for Great Britain this task

9 Mabel Dunlop Grujić, wife of Slavko Grujić, a Serbian diplomat, was among the most active persons in the organization of assistance to Serbia.

10 The Serbian government responded to this note that it was not possible to entrust full freedom of action to the American mission - requested moreover also for General Gorgas - in the whole country, but that in any case total autonomy could be guaranteed in fifteen departments, that is, in all those in the south, except for Niš and Skopje where other missions were already active. [27] 
was entrusted to Colonel William Hunter, for the United States to Strong, for Russia to Sofoterov and for France to Colonel Jaubert. The committee also included the key representatives of the Serbian health sector: Sima Karanović as Head of the Ministry of Defense Medical Department, Đoka Nikolić as Head of the same department of the Ministry of the Interior and, finally, Roman Sondermajer as the military hospitals inspector. [1 p161-2] Strong was also appointed Medical Director: since then he managed the entire system of operation of the French and English doctors and nurses, as well as of the surviving Serb doctors.

The most important aspect of the setting up of the international committee and, therefore, of the coordination of activities, was that the work of the doctors and nurses was not only done for the benefit of the soldiers, but was extended to the civilian population, which had until then remained practically excluded from the possibility of getting treatment. This step was extremely important from the moment when it ceased to be limited to the treatment of the disease and when a prevention system based on the improvement of the hygienic conditions was organized, the goal of which was to stem at the source the spread of typhus and other epidemics, among which cholera had already aroused strong apprehensions. A real "health revolution" as General Gorgas called it, was put in place, "the only possible remedy to defeat the scourge of typhus." [35]

The Serbian parliament approved a 5,500,000 dinar budget for the operation of the committee, [ 1 p59] as the inflow of money and other forms of aid from various European and American organizations continued. Regardless of this, the committee launched appeals for further fundraising and, above all, for the clothes to be sent to the many refugees who still thronged the towns of central and southern Serbia, the most exposed to the epidemics. [36]

One of the first steps taken by the committee was the mapping of the entire country, that is, the analysis of the actual situation and the state of the epidemic not only in towns, but also in the most remotevillages. This sort of a "general health inspection" [ 4 p23] resulted in the planning of the activities and the assessment of emergencies. What was happening among the soldiers was well known and the intervention of foreign missions had in a sense already provided a general picture of the situation; the situation among the civilians amassed in the towns and among the Austro-Hungarian prisoners of war was also clear; what remained to be understoodwas the status of the rural population, of which little was known yet.

The first observations suggested that in the villages, especially in the more isolated ones, typhus had not been as violent as in the rest of the country or that it had not even arrived there. Despite the requisitions for the army that had been in force for several months, in villages the food autonomy had a crucial importance in guaranteeing greater resistance to the typhus. Moreover, Dr. May Berry later observed, "the very high mortality, both in the Serbian epidemic and still more so in the recent epidemic in Rumania, is no doubt largely due to the fact that a large number of those attacked were in a debilitated condition from semi-starvation," [3 p39] a condition 
that was so dominant among the Austro-Hungarian prisoners and among the refugees, but that generally did not involve the rural areas.

Here the best food situation was also accompanied by an (almost) normal course of family and social life, so that those who fell sick received at least constant care from family members and neighbors, who were of fundamental importance in the course of illness. [4 p7] However, despite these first positive observations, the international committee staff had to cope with a very complex situation. An educational prevention campaign was undertaken throughout the country, aimed, above all, at raising awareness of the importance of personal hygiene, the lack of which was often the source of numerous infections in rural areas; [4 p26] meanwhile, measures were introduced to avoid all those situations of people mixing in daily life, such as beds being shared by several people, healthy and sick, the coming and going of people around those who were dying and funeral rituals involving more people - from the dressing of the deceased to their transport to the place of burial - or, finally, the lack of ventilation in the living quarters. [37]

At the same time, they tried to move, at least temporarily, the people from the infected villages in southern Serbia and Macedonia, which seemed to be among those worst affected (the poorest) while trying to encourage the return of refugees from northern Serbia to their homes. [23] The disinfestations, introduced with the aid of very rudimentaryequipment, were the order of the day and included not only clothes and public places, but also housing and often entire villages. [4 p29] In the most affected villages, where no significant results could be achieved or where the proliferation of lice appeared unstoppable, the most extreme measures were applied: the population was evacuated and the buildings burned down. [4 p25] In the towns, which appeared to be the places of death, where the contacts between the sick and the healthy happened daily in homes and public places such as cafes and theaters, the problem of drinking water and sewage was tackled, since the diseases had found a particularly fertile ground in the poor hygienic conditions of the water from the wells and artificial reservoirs; [4 p37] for this reason the committee worked to organize the excavation of artesian wells and to regulate the sewage discharge. [38]

The "health revolution" coordinated by Strong soon yielded its first results, and, probably accompanied by a natural decline in the epidemic, the situation appeared much better already towards the end of April. Among the soldiers, the number of sick people decreased considerably, while among the civilians there were no new outbreaks of the infection; the dreaded cholera, already present on the Eastern front, did not break out, a sign that prevention and treatment were working. 


\section{The victims of the typhus epidemic}

The alarm set off by Dr. Ryan's on the pages of the New York Times when the epidemic had already erupted throughout Serbia, according to which half of the local population would di ewithout an immediate intervention, was, fortunately, refuted. Still, the violence of the typhus swept away the lives of more than half of the Serbian medical personnel, numerous foreign doctors and nurses, and, above all, many soldiers, prisoners of war and civilians.

Among the latter, many refugees from the northern regions who had amassed in the towns of central and southern Serbia and who were forced to live on the streets, without food and clothing and who, therefore, represented (along with the weakened Serbian soldiers, Austro-Hungarian prisoners and the poor) the weakest category, also fell victims to it. The extremely chaotic situation, especially in the initial period of the epidemic, the lack of a health system, the vastness of the regions involved and many other factors prevented the overall death-toll of the typhus epidemic from being precisely established.

At the end of the war, the Serbian delegation to the Peace Conference in Paris presented in the official reports on the civilian and military losses in Serbia the data according to which 360,000 civilians had died due of the typhus and other epidemics, between the end of 1914 and the first half of 1915; [39] the figure, however, collided with the opinions of the most distinguished doctors and scientists who had worked in the field and who had experienced the worst moments of the epidemic. Strong, who remained in Serbia until the autumn to make sure that the typhus was actually defeated, claimed that there was a total of 150,000 deaths in the 6 months of the epidemic; at its peak,as many as 2,500 sick people arrived daily to the military hospitals, while the number of cases of contagion reported among the civilians was at least three times higher then. Mortality ranged from 30 to $60 \%$, depending on the place and conditions, with peaks of 70\%; half of the 60,000 Austro-Hungarian prisoners died of typhus. [4 p6-7] Mortality reached the highest levels where the environment was unhealthier and where people were poorer and weaker; in Đevđelija, where 7,000 people lived, many of them in poverty, it seems that $75 \%$ of the population died before the typhus subsided. [7 p41] These data made Strong admit that "the typhus epidemic that hit Serbia in 1915 was among the most serious ones that the world had seen in the modern era". [4 p3]

Even if defeated, typhus left very serious consequences: in many cases of healing, after a certain period of time, gangrene manifested in $70 \%$ of the cases, leading to death, and, in many others, to the amputation of lower limbs or extremities (in April in Belgrade, the hospital was already full of cases of post-typhus gangrene): the consequences to the muscular and nervous system were also serious. [7 p21-2,37-8]

Dr. Strong would remain in Serbia for a few months to keep the situation under control and avoid any new typhus outbreaks. His commitment, as well as that of the 
other members of his mission, still represents one of the clearest examples of assistance and cooperation between the American and Serbian people.

\section{Rezime}

Krajem 1914. godine u Srbiji izbila je epidemija pegavog tifusa koja se ubrzo proširila na većinu krajeva zemlje. U nedostatku dovoljnog broja lekara i medicinske opreme, sprska vlada obratila se savezničkim i neutralnim zemljama za pomoć. Počeli su da pristižu lekari iz raznih evropskih zemalja, pa čitave sanitetske misije, naročito iz Velike Britanije i Francuske. Ogroman broj žrtava, kako među vojnicima i austrougarskim zarobljenicima, tako i među civilnim stanovništvom, pokazao je razmere epidemije. Strah da će tifus zahvatiti i ostale evropske zemlje, pa čak i SAD, počeo da bude sve prisutniji. U martu 1915. godine, između ostalog kako bi se sprečilo širenje bolesti preko granica Kraljevine Srbije, američki Crveni krst i Rokfelerova fondacija, uz veliku pomoć Srba koji su živeli u Americi, obrazovali su posebnu sanitetsku komisiju sa poznatim epidemiologom doktorom Ričarom Strongom na čelu. Misija je stigla u Srbiju početkom aprila i u saradnji sa već prisutnim misijama uspešno je koordinisala borbu protiv tifusa. Strong je u tom smislu bio jedan od najzaslužnijih lekara za suzbijanje bolesti. Po tadašnjim procenama, tifus je odneo oko 150.000 života.

\section{References:}

1. Đuković I. Tifus u Srbiji 1914-1915 [Typhus in Serbia 1914-1915]. Beograd: Savez udruženja ratnika oslobodilačkih ratova Srbije od 1912. do 1920. godine i potomaka; 2006. $21 \mathrm{p}$.

2. Soubbotitch (Subotić) V. A Pandemic of Typhus in Serbia in 1914 and 1915. Section of Epidemiology and State Medicine 1917 Nov;30:31-39.

3. Fraccaroli A. La Serbia nella sua terza guerra. Milano: Fratelli Treves; 1915. 30 p.

4. Strong R. Typhus fever with particular reference to the Serbia epidemic. Cambridge: American Red Cross - Harvard University Press; 1920. 20 p.

5. Stuart E. Sanitation in Serbia. Am J Public Health 1920 Feb;10:125.

6. Subotić V. Pomenik poginulih i pomrlih lekara i medicinara u ratovima 1912-1918 [Memorial of the killed and dead doctors and medical workers in wars 1912-1918]. Beograd: Srpsko lekarsko društvo; 1922.7 p.

7. Downer EB. The Highway of Death. London: F. A. Davis Company; 1916. p. 23-24.

8. The Archive of Serbia, Ministry of Foreign Affairs Political Department, hereinafter referred to as: AS, MID-PO, 1915, XXI/9, from the Ministry of Defense Health Department, to the Ministry of Foreign Affairs, 13/26 January 1915.

9. AS, MID-PO, 1915, XXI/8, from the Ministry of the Interior, Health Department to the Ministry of Foreign Affairs, 15/28 January 1915.

10. AS, MID-PO, 1915, XXI/33, from the Ministry of Foreign Affairs to the Ministry of the Interior, 15 February/1 March 1915; XXI/33, from the Ministry of the Interior to the Ministry of Foreign Affairs, 16 February/2 March 1915; etc.

11. AS, MID-PO, 1915, XXI/37, from the Ministry of the Interior to the Ministry of Foreign Affairs, 16 February/2 March 1915.

12. Checked Typhus in Europe. The New York Times. 1916 Jul 7 
13. AS, MID-PO, 1915, XXI/49, from the Ministry of the Interior, Health Department to the Ministry of Foreign Affairs, 26 February/11 March 1915.

14. AS, MID-PO, 1915, XXI/62, from the Ministry of the Interior, Health Department, to the Ministry of Foreign Affairs, 17/30 March 1915.

15. AS, MID-PO, 1915, XXI/132, from the Ministry of the Interior Health Department to the Ministry of Foreign Affairs, 10/23 May 1915; XXI/173, 3/16 June 1915; XXI/70, from the Ministry of Defense, Health Department to the Ministry of the Interior, 23 March/5 April 1915.

16. Hunter W. The Serbian Epidemics of Typhus and Relapsing Fever in 1915: Their Origin, Course, and Preventive Measures employed for their Arrest. Proc R Soc Med 191920;13: 34 .

17. AS, MID-PO, 1915, XXI/242 the list of foreign missions and staff on service in Serbia, from the Ministry of Defense, Health Department to the Ministry of Foreign Affairs, 19 March/2 April 1915.

18. AS, MID-PO, 1915, XXI/263, a telegram from the ambassador in Petrograd Spalajković to the Ministry of Foreign Affairs, 20 January/2 February 1915; AS, MID-PO, 1915, XXI/267, a note without signature or addressee, 25 February/9 March 1915.

19. Typhus threatens Serbia, says Lipton. The New York Times. 1915 Mar 15

20. The Scourge of War and Some American Heroism. The American Red Cross Magazine. 1915 Apr

21. Serbia's plague of typhus. The New York Times. 1915 Mar 28

22. Plotz says typhus menaces the world. The New York Times. 1920 Aug 24

23. AS, MID-PO, 1915, XXII/43 and 44, A commencement testimonial to Dr. Richard Pearson Strong, '93 S, for his Serbian Relief Work, in Supplement to the Alumni Weekly, 18 June 1915.

24. AS, MID-PO, 1915, XXII/112, telegram from the Serbian Consul in Paris Vesnić to Prime Minister Pašić, 13/26 January 1915; AS, MID-PO, 1915, XXII/149, from the President of the Parliamentary Refugee Aid Committee (Odbor narodnih poslanika za pomoć izbeglih građana) to Prime Minister Pašić, 17 February/2 March 1915.

25. Terrible conditions in Serbia. The New York Times. 1915 Mar 19

26. Typhus in Serbia killed 100 doctors. The New York Times. 1915 Mar 27

27. AS, MID-PO, 1915, XXII/2, a note by Mabel Grujić, 27 February/12 March 1915. AS, MID-PO, 1915; XXII/4, note from the Ministry of the Interior to the Prime Minister, 28 February/13 March 1915; XXII/6, note from the Prime Minister to the Consulate in New York, 3/16 March 1915.

28. AS, MID-PO, 1915, XXII/181, from the Serbian Consul in New York to the Ministry of Foreign Affairs, 22 March/4 April 1915.

29. Americans to save people of Serbia. The New York Times. 1915 Apr 3

30. AS, MID-PO, 1915, XXII/7, a telegram from the Serbian Consul in New York Pupin to the Ministry of Foreign Affairs, 4/17 March 1915.

31. AS, MID-PO, 1915, XXII/11, a telegram from the Serbian Consul in Paris Vesnić to the Ministry of Foreign Affairs, 26 March/8 April 1915.

32. To combine forces for Serbian Relief. The New York Times. 1915 Mar 31 
33. AS, MID-PO, 1915, XXII/16, from the American Ambassador in Bucharest to Prime Minister Pašić, 8/21 April 1915; AS, MID-PO, 1915, XXII/18, from the Serbian Consul in Sofia to Prime Minister Pašić, 9/22 April 1915.

34. AS, MID-PO, 1915, XXII/14, a note from Prime Minister Pašić to the Consul in Thessaloniki, 4/17 April 1915.

35. Gorgas would need free hand in Serbia. The New York Times. 1915 Apr 14

36. The frightful condition of Serbia. The New York Times. 1915 Apr 25

37. Matthews C. Experiences of a woman doctor in Serbia. London: Mills \& Bonn; 1916. p. 53-4, 56.

38. Ostojić-Fejić U. Sjedinjene američke države i Srbija 1914-1918 [USA and Serbia 19141918]. Beograd: Institut za savremenu istoriju; 1994. p64-5.

39. Stojančević V. Srbija i srpski narod za vreme rata i okupacije 1914-1918. godine [Serbia and Serbian people during the war and occupation 1914-1918]. Leskovac: Narodni Muzej Leskovac; 1988. 21 p.

Received: 23/11/2018

Reviewed: 04/12/2018

Accepted: 12/12/2018 